\title{
Investigación en preservación y trasplante renal
}

\author{
Alcaraz Asensio A. \\ Servicio de Urología. Hospital Clinic i Provincial. Barcelona.
}

Actas Urol Esp. 2008;32(1):1-2

$\mathrm{L}_{\mathrm{g}}^{\mathrm{a}}$ a presentación de un monográfico en investigación es siempre motivo de satisfacción. Si este monográfico es de investigación en trasplante renal, esa satisfacción es aún mayor, fundamentalmente por las especiales circunstancias que rodean la organización del trasplante en España, que se articula alrededor del nefrólogo y el urólogo como principales protagonistas, en contraposición a otros modelos organizativos. E1 segundo aspecto relevante, en cuanto al médico de trasplante, es su capacitación para investigar.

El modelo de trasplante renal en España ha descansado desde sus inicios en las figuras del cirujano de trasplante, asumido en más del 90\% de los centros españoles por el urólogo y el médico clínico de trasplante, asumido también de forma mayoritaria por el nefrólogo. Este modelo ha demostrado ser exitoso en cuanto a los excelentes resultados de supervivencia tanto de pacientes como de injertos. Asimismo, el desarrollo de programas nacionales y leyes avanzadas de trasplante nos ha permitido ser el país con mayor tasa de donación de cadáver mundial.

La figura del cirujano de trasplante, asumida por el urólogo, es singular en cuanto a nuestra dedicación asistencial. Habitualmente, el urólogo maneja al paciente desde el diagnóstico, realiza el tratamiento médico y/o quirúrgico y acaba con el seguimiento del mismo. No es el caso del trasplante renal. En él, actuamos con una visión más técnico-quirúrgica $\mathrm{y}$, una vez pasado el postoperatorio, no desentendemos de su seguimiento. Sin duda, no es la mejor circunstancia para involucrarse en programas de investigación que excedan lo meramente técnico.

El segundo aspecto que sin duda afecta al urólogo o nefrólogo que investiga, es la formación necesaria para llevarla a cabo. Si nos centramos en el urólogo que investiga, tiene un perfil muy definido. Es un urólogo que trabaja en un hospital terciario (algo obvio en el caso del trasplante renal), con la tesis doctoral concluida y relacionado de forma estable con un grupo de investigación básica. Podríamos definirlo como un urólogo académico. Esta figura de urólogo académico en países tradicionalmente importantes en la investigación, está en clara decadencia. Se estima que tan sólo 200 urólogos en USA cumplen los criterios de asistencia, docencia universitaria y haber completado un programa de doctorado (PhD). En Europa y España, la situación no es mejor ante la falta de sensibilidad por parte de autoridades sanitarias y universitarias, de la necesidad de promover este perfil de urólogo. Se hace necesario que las sociedades científicas como AEU y EAU promuevan, mediante becas específicas, este perfil de urólogo.

El presente monográfico cubre aspectos tradicionalmente de investigación quirúrgica, como es la preservación renal, dirigidos tanto a aumentar el tiempo de preservación del órgano como a medir la viabilidad del órgano a trasplantar. Es muy importante volver a señalar, en este punto, que la decisión final de llevar a cabo un trasplante o no es del cirujano. La valoración del riñón a trasplantar, en cuanto a tiempos de isquemia, evaluación macroscópica y valoración de los datos de la biopsia renal, si se hubiera hecho, son responsabilidad última del cirujano. Un fallo primario del injerto debe considerarse como un fracaso, al no haber sido capaces de identificar estos riñones en riesgo. Un segundo aspecto importante abordado en los trabajos de investigación presentados en el presente monográfico, es la cirugía laparoscópica, tanto aplicada al donante vivo como al receptor. Primeros intentos, que algunos considerarán futuristas y otros de poco realistas, del trasplante renal asistido por laparoscopia, pero que nunca 
serían realidad sin el desarrollo de estos modelos en animales de experimentación. Los trabajos de investigación de la nefrectomía laparoscópica de donante vivo han permitido superar los inconvenientes que se identificaron en sus inicios: mayor indice de complicaciones ureterales, mayor índice de NTA y un retraso en recuperar la función del riñón trasplantado.

En definitiva, nos encontramos ante un monográfico que el Dr. Enrique Lledó ha sabido hacer extensivo a los grupos activos en investigación en trasplante en España y, por otra parte, ha cubierto muchos de los aspectos de la potencial investigación en trasplante. Para poderlo conseguir, se han conjuntado en él las dos condiciones necesarias: la primera conocer el panorama español de trasplante y la segunda ser un investigador activo en el tema, en continua interacción con el resto de grupos de investigación en trasplante.

Espero que el urólogo sea capaz de proseguir en su labor investigadora junto con la asistencial. Para ello, será fundamental el mimar desde la Administración al médico, fomentar la promoción Universitaria de los urólogos investigadores y favorecer desde las Asociaciones Profesionales mediante becas la formación de Urólogos Académicos.

Correspondencia autor: Dr. A. Alcaraz Asensio Servicio de Urologia. Hospital Clinic i Provincial Villarroel, 170 - 08036 Barcelona. Tel.: 932275400 E-mail autor: aalcaraz@clinic.ub.es Información artículo: Prólogo 